The Dawn of Something Unknown

Book review essay

Ferguson, James. 2015. Give a Man a Fish. Reflections on a New Politics of Distribution. Duke 2015. 264 pages.

\title{
Introduction
}

Social change can be like an undetected shift in the weather. In one moment, endless blue sky fills the horizon, promising a lazy day of sunshine. Slowly, however, unnoticed clouds appear. Before one knows it, wind rips through trees, rain pounds the ground and one is left wondering how it all could change so fast. Over the last twenty years, there has been a change of weather in the world of development. In a time when activists and scholars have become used to critiquing neoliberal reforms in the Global South - reforms which diminish national sovereignty, lessen government spending and generally "roll back of the state" - something unexpected has happened: Governments and organizations in the south have started to give cash directly, often unconditionally, to the poor. Across Southern Africa, Latin America and in parts of Asia vast social welfare programs and have sprung up distributing cash to millions. Close to every second household in South Africa now receives at least one social cash transfer from the state. In Mexico and Brazil one in four inhabitants receive social grants from the state. In Indonesia, 19 million people get around eight dollars a month, no strings attached, in order to alleviate increasing food prices. A review by the UK state development agency DFID estimates that cash transfer programs now reach up to 1 billion people worldwide (Arnold, Conway, \& Greenslade, 2011). It describes the trend as a "quiet revolution".

James Ferguson's new book, Give a Man a Fish. Reflections on a New Politics of Distribution, is the weather report that takes it upon itself to understand the trend: Where does it come from? How is it organized? And what promises for the future does the present moment hold? 
Ferguson adds his voice to a growing number of studies that are interested in cash transfers. The work differs, however, from what we have seen so far. Part ethnographic review, part anthropological reflection, the book is an exercise in empirically grounded mental gymnastics. It aims to do more than review whether or not cash transfer programs "work". Ferguson seeks to use the empirical record to reflect about taken-for-granted ways of thinking about wealth and poverty. As such, the book attempts a classical anthropological exercise: Make the strange familiar, and the familiar strange.

\section{The familiar}

For a long time, a defining metaphor in development circles has been the proverb: “Give a man a fish, and you feed him for a day. Teach a man to fish, and you feed a man for a lifetime." The familiar saying represents the sentiment behind many development interventions. Southern NGOs commonly experience calls from their Northern donors to become more "sustainable". They ought to become independent and able to source funding for themselves. Funding organizations in the North shy away from donating to dependents, but rather aspire to cooperate with "partner organizations" in the South. Similarly, researchers have documented how a number of contemporary development projects aim to "empower" the poor to become independent. Individuals are "capacitated" through learning work skills or gaining awareness of good governance, human rights or proper sexual behavior. The bogeyman of development work has long been the proverbial handout. Development gifts of the day are not seeds, shovels or cash, but knowledge or awareness.

There is something paradoxical with this way of doing development, which is why it is necessary to put the concepts supporting it - "partner organizations", "empower", "capacitate" - in cautionary quotation marks. Paradoxes of development practice are noticed not least by professionals themselves. In my field research among NGOs in Lesotho, native professionals who gave training sessions in human rights could complain over how aid nowadays no longer 
seemed to mean anything material - yet it was material aid, such as medicines, food or hard cash that the project participants actually needed. Two young native NGO workers grumbled as we drove back from a two-day training seminar on human rights and sexual behavior in a village in rural Lesotho: "How can we empower these people if they sit there and are hungry"? said a young lawyer from the front seat. During the workshop I had noticed how some of the village participants napped off in their chairs. They would only wake up as the lunch break meal was being served. Contradicting the proverb that underpins many development projects, the participants seemed to care little about being taught "how to fish". What mattered was the fish: The meals served during breaks, and the "transport reimbursements" which ought to cover costs of getting to the workshop. Ought to. Such "reimbursements" functioned in reality as a cash grant. At the end of each workshop participants would line up to receive bus and taxi money - only to proceed to walk long journeys on foot back to their homes in neighboring villages. But the NGO workers complained that this cash, distributed to the poor under the radar, was insufficient to really help them. "We need to give them something more. Something they can touch!"

Such grumbles are on to something important, argues Ferguson. The premise of his book is that the world where the saying of "teaching a man to fish" made sense, has changed profoundly. The saying relies on the assumption that if only people are given a chance, skills, capacity, and knowledge, they will be able feed themselves and their families "for a lifetime". This idea, argues Ferguson, is mislead.

\section{The strange}

In many of the rising economies across the global south, the last few decades have been marked by the disturbing phenomenon of "jobless growth". Smaller and smaller amounts of labor produce larger and larger amounts of value. Whereas making a shoe in the post-war economy of the 1940s included a number of specialists who could twirl laces, throb heels, sew seams and leather; today the operation needs only one worker to turn on the machine. Some 
scholars speculate that in a hundred years historians will view the idea of steady, lifetime wage labor as a curious remnant of the industrial revolution. With increasing automation and improved technology, wage labor will no longer be a natural mechanism for distributing wealth. There will simply not be enough meaningful jobs to go around.

Ferguson's point, however, is that scenario of a "job-less economy" is not hypothetical. It is already here. Southern Africa, parts of India and Latin America experience massive oversupply of labor. The problem is not that there are too few trained workers who "know how to fish". It is the opposite: There are too many workers for the economy to absorb.

The fishing industry in Southern Africa is a potent example. Fishing has historically been an important source of subsistence in many areas along the Southern African coast. But today coastal towns swarm with unemployed fishermen. As 1000 new fishing quotas were allocated in one South African town on the Atlantic Coast, more than 4000 unemployed fishermen showed up at the gates seeking work. Ferguson cites a similar example from Zambia. When a fishing company in a coastal town opened for hiring a small number of temporary casual workers, the news spread like wildfire. Before long, more than 5000 jobseekers gathered outside the office gates. The jostling that ensued in the crowd led to a stampede where nine people were killed.

Such cases exemplify a more wide-reaching trend. In South Africa the official unemployment rate is 25 percent. Unofficially the number is closer to 40 , and it is not going anywhere. Ferguson quotes a South African economist who suggests that 10 million citizens can drop dead without making a ripple on the Johannesburg stock exchange. In other words, large portions of the South African population, and indeed the world population, are "simply left out of the global production regime" (Ferguson, 2015: 90). In Africa in general only every fourth able-bodied have steady paid jobs, according to some measures (REF). 
A cold look at such statistics suggests that the development goal of full employment is a fantasy, or in Ferguson's words: a "vanishing dream" (p. 51). The question facing the rising economies of the South today - countries such as India, Brazil and South Africa - is how to organize a society where a large part of the population cannot in any foreseeable future be included through formal and regular wage labor. In other words, what to do with the growing number of people who "from the point of view of the production system" are redundant (Ferguson).

\section{From production to distribution}

It is in this context that the question of distribution emerges at the center of politics. To many development critics' surprise, major institutions have started to recognize the problem posed by the automation and the massive oversupply of labor. The World Bank, for example, has become a leading advocate for expanding cash transfers as a central way of addressing poverty. Among funders and policymakers there is growing support for cash-grant charities like Give Directly, which sets up technology that allow private donors to wire cash, directly and unconditionally, to the bank-accounts of poor individuals in Eastern Africa. Governments in the South have begun to roll out cash distribution programs. In Europe and the US, the idea of basic income grants has moved from the fringe to the center of many political debates. Although not yet enacted as policy, some form of basic income are advocated by green parties across the European continent, including in Germany, the UK and Scandinavia - while the US presidential candidate Bernie Sanders and the former head of the UK Labour Party, Ed Miliband, have both been supportive of the idea, as have hard-core market liberalists such as Milton Friedman. Part of what makes such strange bedfellows is the way that basic income schemes can fulfill ideals both on the classical left and on the right spectrum of politics. Liberalists see in basic income campaigns a way to empower individuals with little involvement of the state, and to promote the efficiency of markets. Social democrats can appreciate the egalitarian appeal of basic income. Some on the left see it as a form of social protection at a time when jobs in the productive sector are increasingly manned 
by robots. While basic income and other cash grants can "fit" old preferences on both left and right, Ferguson argues that what is most interesting is the way such policies deeply challenge our habits of thinking, regardless of political affiliation. There are significant variations in the programs that are being tested. In some initiatives the money given is conditional. The programs target specific groups such as the disabled, women or children. Others are universal in scope, and give to all citizens of a country or a smaller region. Some cash transfer programs are offered for a limited period of time, others are longer lasting. The most radical cash transfer initiatives out there call on governments to establish a basic income, which can be universal, unconditional and life lasting. In South Africa and Namibia campaigns are growing to pressure governments recognize that access to cash is a right of national citizenship. In sum, the "quiet revolution" identified by DFID is real and ongoing. What merit does it deserve? What promise is held by the growing popularity of cash transfers?

Cash transfer initiatives face a number of serious criticisms. Many assume that "hand-outs" possibly cannot work in the long term, since the poor who are given money will either waste it - filling up bars and brothels - or spend it on shortterm alleviation of poverty, and thus fail to address the underlying causes of their misery. Many a development project contains a version of this hidden suspicion and paternalism. A corresponding line of assessment comes from certain corners of the political left. They argue that cash grants take the edge off the hunger, and demobilize a class of people who potentially could have been political aware. Give-away money, in other words, makes people passive.

Both lines of criticism are misguided, argues Ferguson. First of all, a growing number of controlled studies of cash transfer initiatives conclude that the idea that poor people do not know how to spend money wisely is false. Available data show that people use cash transfers reasonably, creatively and effectively. They eat better, buy schoolbooks and start small businesses. For anyone who has done field research in resource-poor settings, this should not come as a surprise. Poor people are not poor because they are irresponsible. They are poor because they happen to be born in places like rural Lesotho. Giving people money thus seems 
like a commonsensical way to empower people - empowering interpreted in the strong sense of making a real transfer of power.

What then about the expectation that people who are given cash grants become politically immobilized? Will not cash grants inevitably produce a force of halfsatisfied consumers, unable to recognize real political conflicts? Ferguson finds little evidence to support that cash transfer programs in fact immobilize the masses. There are few signs that people who are given a share of their resources come to have lower expectations of their governments. On the contrary, the opposite might be the case: As people who have seen nothing but neglect from the state finally are given a share of wealth, they may start to want more.

A third unease about cash transfer programs is closer to the author's own realm of theorizing: Is not cash transfers yet another form of "anti-politics", a technical initiative that is unable to address the underlying causes of poverty? Many associate Ferguson with his earlier conceptualization of a large-scale development project as an "anti-politics machine" (Ferguson 1994). The study documents how a World Bank-funded project in Lesotho insistently reposed political questions of land, resources, jobs and wages as "technical 'problems' responsive to technical 'development' interventions" (1994: 270). Blinded by the technical discourse of "development", the project workers overlooked or misinterpreted the problems that the poor actually faced.

Returning to cash transfers, is this not another example of an attempting to address a deeply political problem of global poverty using a technical quick fix? And hence, does it not fall under Ferguson's own critique of how initiatives take politics out of poverty? Give a Man a Fish argues for the opposite possibility. Ferguson suggests that rather than turning poverty into a non-political question, the technocratic cash transfer initiatives that are now spreading can re-organize the way we think about politics altogether.

It may be too early to wave our flags in full support of cash transfers. But neither is it time to lean back, as many scholars have tended to, and cynically denounce 
whatever hopeful initiative is presented before them. The time has come for directing detailed empirical attention towards the world of cash transfers and new welfare programs. As Ferguson leans in to investigate, he finds reasons for careful optimism. Something profound can be happening that will alter the way we think about poverty, politics and relationship between state and citizens. A new "politics of distribution" is emerging across the Global South. At the heart of the matter is a simple and possibly world-changing idea: The idea of the rightful share.

\section{Mental gymnastics}

It takes some mental practice to get into the way of thinking that Ferguson proposes. Taking a step back, we can ask what all development initiatives take for granted, if broken down to basics. All such initiatives can be understood as some way of giving wealth of rich people - material or immaterial - to the poor. The campaigns that rally for basic income grants, which Ferguson puts under the looking glass, challenge this basic logic.

He takes particular interest in Namibia, where basic income campaigns have a strong voice in the public debate. Campaigners are calling for a basic income grant that is explicitly not considered as a gift to the poor, which should be given to the unfortunate out of a moral commitment. We are not talking about alms, reserved for those who cannot work. Neither is the money seen as a market commodity, something which one exchanges for labor. The reasoning suggests instead that we should all get a social payment because that money is, at the starting point, ours. The sentiment is summed up in the slogan of a recent region-wide campaign across the entire Southern African Development Community: "Our Right - Our Wealth - Our Share" (p. 183). People calling for a basic income, or other varieties of generous welfare grants, claim their right to a legitimate share of their own wealth as members of a society.

Many would ask how such initiatives should be financed. In Namibia campaigners look around and say: “Don't tell me this is a poor a country. Look at 
all the cars, look at all the diamonds, look at all the uranium. If it is not a poor country, why are we not getting our rightful share?" (p. 182). In detail, campaigners argue that a citizen's income can be funded by levies on the country's mineral extraction. But underlying their claims is the idea that these resources in fact belong to the population as a whole - a claim that can be expanded beyond settings with mineral resources. It is "my oil", "my diamonds", and more generally: "my wealth".

Critiques are often raised at development aid for being paternalistic and producing stigma among recipients. If someone gets help because they are materially poor, handicapped, female or so on, it could contribute to blinking them out such as helpless and in some way a burden on society. But if one gets some cash rightful share, because it is in depth your money, along with everyone else in the nation - such stigma could evaporate. And what is more, a new type of relationship between citizens and state can develop from such initiatives. Basic income or other similar social grants can help populations develop a positive "claim-making relationship" to the state. In other words: As it becomes taken for granted that the government is capable and able to deliver payments, a stimulating precedent can be in the making. To expand the metaphor: Those who are given fish - interpreted as their rightful share - are not likely to say thank you and politely lean back; but may rather become dissatisfied and possibly protest next time someone fails to distribute what is rightly theirs.

Going beyond the Southern African context, Ferguson explores example where such funding already exists. In Alaska all the state's legal citizens are shareholders in a portion of the wealth produced by the oil industry. Every year the state residents receive a check drawn from the state's mineral wealth. The reasoning is that the gains from the national oil reserves should be distributed directly to the state's population, not because they participate somehow in oil production, but because they hold a legal status as state residents. (p. 56-57). The Norwegian Government Pension Fund is a similar case. Set up to preserve the gains of mineral extraction for the population, the Norwegian oil fund also 
draws on the idea that the people as a whole is the rightful inheritor to a part of the nation's wealth.

Norwegians or Alaskans, however, are not the first to think along the lines of a rightful share. Anthropologists identify the underlying reasoning from huntergatherer societies. As a pack of hunters would return to their home community with game, the meat is distributed ritually in public in an egalitarian fashion to all inhabitants. The resources are distributed not as a favor or gift, but as wealth in which members already have rights. The idea behind cash grants is the same. From NGO initiatives to government cash transfer programs like the Brazilian Bolsa Familia, we are starting to see people thinking about social payment not as social assistance, not as help for the helpless, but as something one is entitled to because it is, as wild as it may seem, their right.

\section{Conclusion}

The implications of the trend Ferguson has pointed out are broad. "Give a Man a Fish" suggests that with the increasingly popular cash transfer programs, a seed has been planted in powerful circles - an idea which could grow into a completely new way of thinking about poverty, political mobilization and relationship between state and citizens. This remains to be seen - and investigated by social researchers.

From the viewpoint of social scientists, a fresh research agenda is emerging, investigating the world of cash transfer. Expanding from the narrowly defined anthropology or sociology of development encounters, social researchers will be encouraged by the book to pay closer attention to distributive mechanisms more generally in resource-scarce settings.

For example, what kinds of skills are needed to make distributive flows possible in chains of development assistance, from the imagined "top" to "bottom" - from government- and donor offices to middle-range organizations, to villagers, 
recipients and other project participants? To make funds flow one often requires particular types of practices that help build enduring social relationships. Taking the viewpoint of local foreign-funded NGOs, this includes writing an endless stream of reports, accompanying donors on field visits, and otherwise carefully building trust, understanding and feelings of obligation. This could be seen as what Ferguson terms "distributive labor": hard and persistent work that allows one to make legitimate claims on other people's resources. He gives the example unemployed South African men and women who work meticulously in order to establish themselves as the "dependents" of relatives with regular access to resources. Material dependence in this sense is not a passive condition, as it is sometimes interpreted in development critiques, "it is a valued outcome of long, hard social labor" (p. 97).

Give a Man a Fish is a strangely stimulating read. It contains a mixture of empirical research, anthropological reflection and political philosophy. Such an ambitious blend is unsurprisingly not without shortcomings. A philosopher would possibly want more careful reasoning about the idea that all members of society have a right to a share in a nation's common wealth. Where does this right come from? Who has a right, and who do not? Where to set the boundaries? Answers to such questions are not discussed by Ferguson. He quotes political philosophers such as Philippe van Parijs and Thomas Pogge without going into detail about their arguments and opponents.

Conversely, perhaps, some anthropologists could want more empirical research at the cost of philosophical reflection. Ferguson does pay close attention to the public debate over cash grants across Southern Africa, and has done some investigations among welfare bureaucrats and policy makers in the region. The book relies on solid empirical work of others, such as the detailed studies of social grants and economic informality in South Africa (e.g. Neves and du Toit, 2012; Neves et. al, 2009). However, there are parts of the book where one is left wanting more research digging directly into the ideas that Ferguson proposes. 
The book consists of chapters that were originally given as the annual series of Lewis Henry Morgan lectures. As they were developed for the book format they could have benefited from a round of more wholesome editing. Central points and formulations are repeated throughout. We are told in close to every chapter a similar story about how today is an era of labor surplus, where the importance of wage work is decreasing. Similarly we are told in the intro, chapter one, two and three about the Marxist critique of cash grants. Such repetitions give readers the feeling of taking a step back for every chapter. Fortunately, they also proceed by taking two steps forward.

The slow pace of the author's reflection has its strength. The work has been brewing apparently without haste ever since well before Ferguson's last collection of essays (2010). He is out not to convert readers, but rather invite them along to discover and reflect thoroughly about a phenomenon which blurs ideological dividing lines. The result is a line of thought that is more persuasive than most polemics, a monograph that is empirically grounded yet analytically contagious.

Viewed through the lens of Give a Man a Fish the world starts to look a shade different. Where one earlier saw beggars asking for your money, one can now appreciate such phenomena as individuals requesting a rightful share in a pool of wealth that also belongs to them. Similarly, a Latin-American woman expressing her commitment and hardship in an e-mail to a Western man abroad now appears to be engaged in "distributive labor": Working to acquire the carefully cultivated status of being someone's dependent, and thus able to make a legitimate claim to their wealth. Finally, where one earlier thought of development assistance as a way to send our resources to the poor, we can now consider a different alternative: That people who are at the receiving end of aid flows are only being given back some of the resources that they have been robbed of through an unjust division of power. To distribute resources to them is not so much giving away something that is ours, but rather sharing a piece of that which is, in fact, rightfully theirs. 


\section{References:}

Arnold, C, T Conway, \& M Greenslade. 2011. Cash transfers literature review. London: Department for International Development.

Englund, Harri. 2006. Prisoners of freedom : human rights and the African poor. Berkeley: University of California Press.

Ferguson, James. 1990. The Anti-Politics Machine: "Development", Depoliticization and Bureaucratic Power in Lesotho. New York: Cambridge University Press.

Ferguson, James. 2010. Global Shaddows. Duke University Press

Ferguson, James. 2015. Give a Man a Fish: Reflections on the New Politics of Distribution. Duke University Press.

Stirrat, R. L., \& H. Henkel. 1997. The Development Gift: The Problem of Reciprocity in the NGO World. The ANNALS of the American Academy of Political and Social Science 554(1): 66-80.

Neves, David, and Andries du Toit. 2012. Money and Sociality in Southe Africa's Informal Economy. Africa 82 (1): 131-49

Neves, David Michael Samson, Ingrid van Niekirk, Sandile Hlatshwayo, and Andies du Toit. 2009. The Use and Effectiveness of Social Grants in South Africa. Cape Town: Institute for Poverty, Land and Agrarian Studies (PLAAS), University of Western Cape; Economic Policy Research Institute (EPRI), University of Cape Town; and FinMark Trust.

Ståle Wig,

PhD Candidate

Dept. of Social Anthropology

University of Oslo

stale.wig@sai.uio.no 
$\underline{\text { Ståle Wig is a PhD candidate in Social Anthropology at the University of Oslo. He }}$ has done ethnographic fieldwork among development professionals in Lesotho (2011-2012), and is currently doing doctorate fieldwork in Cuba, on the rising. 